\title{
Front Matter: Volume 8751
}

, "Front Matter: Volume 8751," Proc. SPIE 8751, Machine Intelligence and Bio-inspired Computation: Theory and Applications VII, 875101 (6 June 2013); doi: $10.1117 / 12.2032001$

Event: SPIE Defense, Security, and Sensing, 2013, Baltimore, Maryland, SPIE. United States 


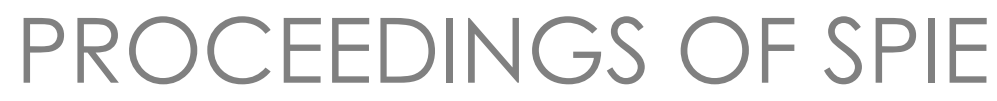

\section{Machine Intelligence and Bio-inspired Computation: Theory and Applications VII}

Misty Blowers

Olga Mendoza-Schrock

Editors

2 May 2013

Baltimore, Maryland, United States

Sponsored and Published by

SPIE

Volume 8751 
The papers included in this volume were part of the technical conference cited on the cover and title page. Papers were selected and subject to review by the editors and conference program committee. Some conference presentations may not be available for publication. The papers published in these proceedings reflect the work and thoughts of the authors and are published herein as submitted. The publisher is not responsible for the validity of the information or for any outcomes resulting from reliance thereon.

Please use the following format to cite material from this book:

Author(s), "Title of Paper," in Machine Intelligence and Bio-inspired Computation: Theory and Applications VII, edited by Misty Blowers, Olga Mendoza-Schrock, Proceedings of SPIE Vol. 8751 (SPIE, Bellingham, WA, 2013) Article CID Number.

ISSN: 0277-786X

ISBN: 9780819495426

Published by

SPIE

P.O. Box 10, Bellingham, Washington 98227-0010 USA

Telephone +1 3606763290 (Pacific Time) · Fax +1 3606471445

SPIE.org

Copyright @ 2013, Society of Photo-Optical Instrumentation Engineers.

Copying of material in this book for internal or personal use, or for the internal or personal use of specific clients, beyond the fair use provisions granted by the U.S. Copyright Law is authorized by SPIE subject to payment of copying fees. The Transactional Reporting Service base fee for this volume is $\$ 18.00$ per article (or portion thereof), which should be paid directly to the Copyright Clearance Center (CCC), 222 Rosewood Drive, Danvers, MA 01923. Payment may also be made electronically through CCC Online at copyright.com. Other copying for republication, resale, advertising or promotion, or any form of systematic or multiple reproduction of any material in this book is prohibited except with permission in writing from the publisher. The CCC fee code is 0277-786X/13/\$18.00.

Printed in the United States of America.

Publication of record for individual papers is online in the SPIE Digital Library.

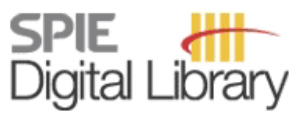

SPIEDigitalLibrary.org

Paper Numbering: Proceedings of SPIE follow an e-First publication model, with papers published first online and then in print and on CD-ROM. Papers are published as they are submitted and meet publication criteria. A unique, consistent, permanent citation identifier (CID) number is assigned to each article at the time of the first publication. Utilization of CIDs allows articles to be fully citable as soon as they are published online, and connects the same identifier to all online, print, and electronic versions of the publication. SPIE uses a six-digit CID article numbering system in which:

- The first four digits correspond to the SPIE volume number.

- The last two digits indicate publication order within the volume using a Base 36 numbering

system employing both numerals and letters. These two-number sets start with 00, 01, 02, 03, 04, $05,06,07,08,09,0 A, 0 B \ldots 0 Z$, followed by 10-1Z, 20-2Z, etc.

The CID Number appears on each page of the manuscript. The complete citation is used on the first page, and an abbreviated version on subsequent pages. Numbers in the index correspond to the last two digits of the six-digit CID Number. 


\title{
Contents
}

\author{
$\checkmark \quad$ Conference Committee \\ vii Introduction
}

\section{SESSION $1 \quad$ ADVANCED APPROACHES FOR IMAGE PROCESSING}

875102 Optimization of background subtraction for image enhancement [8751-1]

L. Venetsky, R. Boczar, R. Lee-Own, Naval Air Engineering Ctr. (United States)

875103 Statistical recognition of 3D objects using integral imaging [8751-2]

C. M. Do, Univ. of Connecticut (United States)

875105 Spatial context for moving vehicle detection in wide area motion imagery with multiple kernel learning [8751-4]

P. Liang, Temple Univ. (United States); D. Shen, Intelligent Fusion Technology, Inc. (United

States); E. Blasch, K. Pham, Air Force Research Lab. (United States); Z. Wang, G. Chen,

Intelligent Fusion Technology, Inc. (United States); H. Ling, Temple Univ. (United States)

\section{SESSION 2 INFORMATION FUSION}

875107 Fusing video and text data by integrating appearance and behavior similarity [8751-6]

G. Levchuk, C. Shabarekh, Aptima Inc. (United States)

\section{SESSION 3 CYBER OPERATIONS I}

875109 Trusted computation through biologically inspired processes [8751-10]

G. W. Anderson, MacAulay-Brown, Inc. (United States)

8751 OA A developmental approach to learning causal models for cyber security [8751-11] J. Mugan, 21CT, Inc. (United States)

$8751 \mathrm{OB} \quad$ Computational intelligence and neuromorphic computing potential for cybersecurity applications [8751-12]

R. E. Pino, M. J. Shevenell, ICF International (United States); H. Cam, P. Mouallem, J. L. Shumaker, U.S. Army Research Lab. (United States); A. H. Edwards, Air Force Research Lab. (United States)

\section{SESSION 4 CYBER OPERATIONS II}

8751 OD A pipelined FPGA implementation of an encryption algorithm based on genetic algorithm [8751-14]

N. Thirer, Holon Institute of Technology (Israel) 


\section{SESSION 5 REMOTE SENSING}

8751 OF Vehicle tracking and analysis within a city [8751-17]

Y. Liang, M. Henderson, S. Fernandes, Central State Univ. (United States); J. Sanderson, Wright State Univ. (United States)

8751 OG Applying manifold learning to vehicle classification using vibrometry signatures [8751-18] S. Kangas, O. Mendoza-Schrock, A. Freeman, Air Force Research Lab. (United States)

$8751 \mathrm{OH} \quad$ Electro-optical seasonal weather and gender data collection [8751-19]

R. McCoppin, N. Koester, H. N. Rude, M. Rizki, L. Tamburino, Wright State Univ. (United States); A. Freeman, O. Mendoza-Schrock, Air Force Research Lab. (United States)

Author Index 


\section{Conference Committee}

Symposium Chair

Kenneth R. Israel, Major General (USAF Retired) (United States)

Symposium Cochair

David A. Whelan, Boeing Defense, Space, and Security

(United States)

Conference Chairs

Misty Blowers, Air Force Research Laboratory (United States)

Olga Mendoza-Schrock, Air Force Research Laboratory (United States)

Conference Program Committee

Dale E. Courte, University of Dayton (United States)

Michael R. Peterson, University of Hawai'i (United States)

Robinson Pino, ICF International (United States)

Mateen M. Rizki, Wright State University (United States)

Todd V. Rovito, Air Force Research Laboratory (United States)

Clare Thiem, Air Force Research Laboratory (United States)

Juan R. Vasquez, Air Force Research Laboratory (United States)

Jonathan R. Williams, Air Force Research Laboratory (United States)

Bryant T. Wysocki, Air Force Research Laboratory (United States)

Session Chairs

1 Advanced Approaches for Image Processing

Ryan McCoppin, Wright State University (United States)

2 Information Fusion

Misty Blowers, Air Force Research Laboratory (United States)

3 Cyber Operations I

Jonathan R. Williams, Air Force Research Laboratory (United States) 
4 Cyber Operations II

Robinson Pino, ICF International (United States)

5 Remote Sensing

Misty Blowers, Air Force Research Laboratory (United States)

Proc. of SPIE Vol. $8751875101-6$

Downloaded From: https://www.spiedigitallibrary.org/conference-proceedings-of-spie on 26 Apr 2023 Terms of Use: https://www.spiedigitallibrary.org/terms-of-use 


\section{Introduction}

The "Machine Intelligence and Bio-inspired Computation: Theory and Applications VII" conference was back by popular demand, settling into its seventh year at the SPIE Defense, Security, and Sensing 2013 symposium. Numerous interesting presentations were made by some of the brightest luminaries in the Computational Intelligence and Defense communities; covering such topics as advanced approaches for image processing, information fusion, remote sensing, and machine learning applications to cyber operations (new this year!).

As always, any conference is only as good as the planners, authors, presenters and attendees make it. Despite all the challenges affecting government spending, we still had a great turn-out. Special thanks to Capt. Jonathan Williams who stepped in as conference co-chair and who was instrumental in helping the conference run smoothly. Some attendees traveled at their own personal expense, which speaks volumes to the quality and dedication to this conference. For those of you who attended, we hope you came away a little more enlightened than when you arrived. We sincerely hope you appreciate the papers that follow, and that they serve to foster further research into, and application of, evolutionary and bioinspired computation. We look forward to seeing you next year at "Machine Learning and Bio-Inspired Computation: Theory and Applications VIII," to be held at the SPIE Defense, Security, and Sensing Symposium in the Baltimore Convention Center, Baltimore, MD.

Misty Blowers Olga Mendoza-Schrock 
Proc. of SPIE Vol. $8751875101-8$

Downloaded From: https://www.spiedigitallibrary.org/conference-proceedings-of-spie on 26 Apr 2023 Terms of Use: https://www.spiedigitallibrary.org/terms-of-use 